\title{
Effects of dietary calcium on growth and oviposition of the African land snail Limicolaria flammea (Pulmonata: Achatinidae)
}

\author{
Rosemary I. Egonmwan \\ Department of Zoology, University of Lagos, Akoka, Lagos, Nigeria. Tel: 2341 5454891; Fax: 2341 4932669; \\ egone@infoweb.com.ng
}

Received 01-III-2006. Corrected 29-VIII-2006. Accepted 14-V-2007.

\begin{abstract}
In an attempt to elucidate the role of calcium in the life of the edible Achatinid snail, Limicolaria flammea (Müller) I investigated short and long term effects of calcium added to the food. The short term experiments lasted for 18, 30 and 32 weeks respectively, while the long term experiment to determine life time utilization of calcium carbonate lasted for 15 months. In the short term experiments, hatchlings were divided into densities of one, ten and 50 snails. In the 10 snail group, there was a positive correlation between calcium provision, body weight ( $\mathrm{t}$ test, $\mathrm{p}<0.01 ; \mathrm{r}=0.96, \mathrm{p}<0.0001$ ) and shell length ( $\mathrm{t}$ test, $\mathrm{p}<0.01 ; \mathrm{r}=0.96, \mathrm{p}<0.00001$ ). There was also a positive correlation between increase in shell length and availability of calcium in the 1 snail group ( $\mathrm{t}$ test, $\mathrm{p}<0.01 ; \mathrm{r}=0.99, \mathrm{p}<0.00001)$. In the 50 -snail group, the correlation was positive for shell length of the snails (t test, $\mathrm{p}<0.05 ; \mathrm{r}=0.99, \mathrm{p}<0.0001$ ) and body weight (t-test, $\mathrm{p}<0.05 ; \mathrm{r}=99, \mathrm{p}<0.00001$ ). Mortality was very high in the snails deprived of calcium and they did not produce eggs. In the long term experiment, there were three feeding peaks in L. flammea. In the first feeding peak, amount of food and calcium ingested by the snails increased in the first three months of life. The second feeding peak occurred at six months of age, while the last occurred at 10 months of age. The amount of calcium ingested during the second peak decreased gradually in the 4 th and $5^{\text {th }}$ month. The amount of calcium ingested was lowest during the $3 \mathrm{rd}$ feeding peak. The period of highest weight gained by the snails was between the 1st and 6th month and then dropped at between six and 12 months of age which corresponds to the period of egg production. There were also three peaks of egg production; the first was between six and eight months (535 eggs), the second at between 10 and 11 months (350 eggs) and the third at 13 to 14 months (310 eggs) respectively. Rev. Biol. Trop. 56 (1): 333-343. Epub 2008 March 31.
\end{abstract}

Key words: calcium, growth, life time utilization, oviposition, Limicolaria, Achatinidae.

Dietary calcium is an essential nutrient for growth and reproduction and construction of the shell in terrestrial gastropods (Boycott 1934, Wagge 1952, McKillop and Harrison 1972, Crowell 1973, Tompa and Wilbur 1977, Peake 197 insoluble salts of calcium carbonate was one of the major steps in colonization of land by various groups of gastropods (Tompa 1980). Snail hatchlings need to build a strong shell soon after emergence and the parental effort extends in some species to providing calcium-rich faeces or coating the eggs with a layer of calcium-rich soil (Tompa 1980). Some snails select sites for oviposition which provide supply of calcium after emergence (Beeby and Richmond 1988).

The most important site of calcium deposition in the gastropods is the shell, where it constitutes $97 \%$ of the shell weight (Heller and Magaritz 1983) and it is laid down almost exclusively as calcium carbonate (Ireland and Marigomez 1992). Calcium is also deposited in the digestive gland, connective tissue cells, foot tissue and around major blood vessels (Tompa and Watabe 1976, Simkiss and Mason 1983, Ireland and Marigomez 1992). Most of the calcium absorbed by terrestrial gastropods may enter the animal's body via the epithelium 
of the intestine (Beeby and Richmond 1988, Dallinger et al. 2001) or through the integument (Simkiss and Wilbur 1977, Ireland 1982). Calcium cells are present in the integument of a wide range of pulmonates (Fournie and Chetail 1982, Luchtel and Deyrup-Olsen 2001).

Calcium provision to the eggs is a major cost to the parent, for example, Deroceras lose about $20 \%$ of their total calcium reserve at each oviposition (Fournie and Chetail 1982). Provision of calcium carbonate and nutrients to the shell is the most common form of parental investment (Baur 1994) and among the gastropods a variety of strategies are used to ensure sufficient calcium for the hatchlings to build a shell after emergence (Beeby and Richmond 2001).

Diets based on green vegetables do not ensure a good growth rate of terrestrial snails (Gomot et al. 1989), and the plant matter upon which the land snail feed is not a sufficient source of calcium (Crowell 1973) and land snails fed on lettuce only result in weak, thin and fragile shells (Crowell 1973). Therefore, some species have been very selective in their habitat preference (Chang and Emlen 1993) and choice of food (Baur et al. 1994, Hanley et al. 1995, Linhart and Thompson 1995, Dallinger et al. 2001). The uptake and storage of trace elements such as copper, zinc, cadmium and lead by terrestrial gastropods are connected intimately with the uptake and storage of calcium (Beeby and Richmond 1988, Beeby 1991, Dallinger et al. 2001).

This paper investigates life time utilization of calcium and the influence of omitting calcium carbonate from the diet on the growth and fecundity in Limicolaria flammea (Müller).

\section{MATERIALS AND METHODS}

Biological materials: Snails used in the experiment were the progeny reared in the laboratory from eggs produced by the parent stock colony obtained from Iguobazuwa village, near Benin-city which is located in the rainforest area of Southern Nigeria, about $250 \mathrm{~km}$ South east of Lagos (latitude $06^{\circ} 19^{\prime} \mathrm{N}$, longitude $05^{\circ}$ $\left.36^{\prime} \mathrm{E}\right)$. They were maintained in a temperature controlled room with uniform illumination (light: dark $=12 \mathrm{~h}: 12 \mathrm{~h}$; temperature $=25.0 \pm$ $1{ }^{\circ} \mathrm{C}$; relative humidity $=60 \%$ ) with the light phase beginning at $7 \mathrm{am}$.

Growth experiment: Immediately after hatching, 188 hatchlings of L. flammea from five egg clutches were weighed using a Mettler AE100 balance (correct to $0.1 \mathrm{mg}$ ) and the shell length of each was measured using a vernier caliper. The hatchlings were divided into densities of one (48 group), ten (four groups) and 50 (two groups) in clear plastic boxes of various sizes and lined with wet tissues. Half of the groups at each density were provided with excess lettuce, apple, potato and carrot and calcium carbonate in the form of natural chalk (control) while the other half (experimental) were provided with the same excess food but no chalk. The experiments continued for 18 weeks (single snails), 32 weeks (10 snails group) and 30 weeks (50 snails group) respectively during which time the snails were weighed and length of shell measured every week and any eggs laid were counted. The boxes were washed weekly, when the wet tissue lining was changed. At the end of the experiments all the animals were dissected and the wet weights of the shell and body were obtained. The mean snail body weight and shell length was plotted against time for each breeding condition.

The relationship between Shell length and body weight of snails provided calcium and those without calcium were subjected statistically to Student t- test and Pearson productmoment correlation (Dytham 2004).

Life time utilization of calcium: A clutch of 40 eggs of L. flammea which hatched the same day were used for this experiment. The hatchlings were placed in four groups of 10 each in four plastic boxes kept in a controlled climatic condition in the laboratory. The hatchlings were weighed and measured immediately after hatching and then every week. The snails were fed on a mixture of weighed food 
consisting of carrots, apples, potato and lettuce and calcium carbonate in form of natural chalk. To estimate the weight of food eaten by the snails, the food material was divided into two parts, one half was weighed and given to the snail while the other half was weighed and then dried to a constant weight for 7 days in an electric oven set at $60{ }^{\circ} \mathrm{C}$. At the end of each week the uneaten food was dried to a constant weight in the same electric oven for 7 days and the dried weight of the food eaten by the snails was calculated. The snails were weighed and measured before new food is provided at the same time of day. The experiment lasted for 15 months and was terminated when more than $80 \%$ of the snails died due to old age. The numbers of eggs laid by the snails during the period were counted. The mean snail weight, shell length, amount of dry food and natural chalk ingested, number of eggs laid were plotted against time.

\section{RESULTS}

\section{Calcium consumption and somatic} growth: The results of the effect of calcium deprivation on the growth of $L$. flammea are shown (Fig. 1, 2 and 3). The experiments were carried out at various times during the year and lasted for different periods of 18 weeks for the 1 -snail group, 30 weeks for the 50 -snail group and 32 weeks for the 10 snail group.

At the start of the experiment the mean weight of the 10-snails group was $29.0 \mathrm{mg}$ and their shell length was $4.5 \mathrm{~mm}$ (Fig. 1). It is clear from the figure that, although the form of growth is similar in the experiment and control groups, lack of calcium has a profound negative effect on snail growth from the very start of life. The growth differential of snails with and without calcium increased dramatically at the 4th month of life when normal growth rate is maximal. Growth was highly correlated with provision of calcium carbonate and by the 20th week the communally reared snails in the 10 snail groups deprived of calcium are approximately one quarter the weight and two-thirds the length of the control snails: at 20 weeks the mean weight of experimental snails was $597.5 \mathrm{mg}$ with shell length of $15.65 \mathrm{~mm}$ while the mean weight of the controls was $2100 \mathrm{mg}$ (t-test, $\mathrm{p}<0.01 ; \mathrm{r}=0.96, \mathrm{p}<0.0001$ ), and shell length was $25.13 \mathrm{~mm}$ (t-test, $\mathrm{p}<0.01 ; \mathrm{r}=0.96$, $\mathrm{p}<0.00001)$.

In the 50-snail group, again snails deprived of calcium grew more slowly than the control group (Fig. 2). At the end of 30 weeks the mean weight of the experimental group was $950 \pm 70$ $\mathrm{mg}$ and the shell length was $17.5 \pm 0.75 \mathrm{~mm}(\mathrm{t}$ test, $\mathrm{p}<0.05 ; \mathrm{r}=0.99, \mathrm{p}<0.0001$ ) while in the control group the mean body weight was 1150 $\pm 70 \mathrm{mg}$ and shell length was $20.75 \pm 0.75 \mathrm{~mm}$ (t-test, $\mathrm{p}<0.05 ; \mathrm{r}=99, \mathrm{p}<0.00001$ ).

Snails reared singly (Fig. 3) also showed reduced growth rate when deprived of an external calcium source ( $\mathrm{t}$ test, $\mathrm{p}<0.01 ; \mathrm{r}=$ $0.99, \mathrm{p}<0.00001)$, but the experiment was terminated just before the period of accelerated normal growth and so the difference between the experimental and control snails was still relatively small by the end of the observation period but it was highly significant $\left(\mathrm{r}^{2}=\right.$ 0.9933, $\mathrm{p}=0.00001$ ).

Mortality was high from week 12 onwards in the two communally reared calcium deprived groups, so that by the end of the experiments $60 \%$ of the snails had died in both the 10 -snail and $80 \%$ in 50 -snail groups. $10 \%$ mortality was recorded in the two control communally reared groups provided with calcium carbonate while none from the group reared singly with or without calcium carbonate. It was observed that in the communally reared snails, the snails without calcium ate from the shells of other live snails and also the remains of dead snails, and this additional boost of calcium may have permitted the hint of normal growth spurt at 4 months of age in the experimental communally reared snails (Fig. 1 and 2).

When the control snails in the 10-snail group started egg laying at the age of 6 months the experimental snails were still too small and by the time the experiment was terminated none of the experimental snails had laid any eggs while the control group had laid eight 

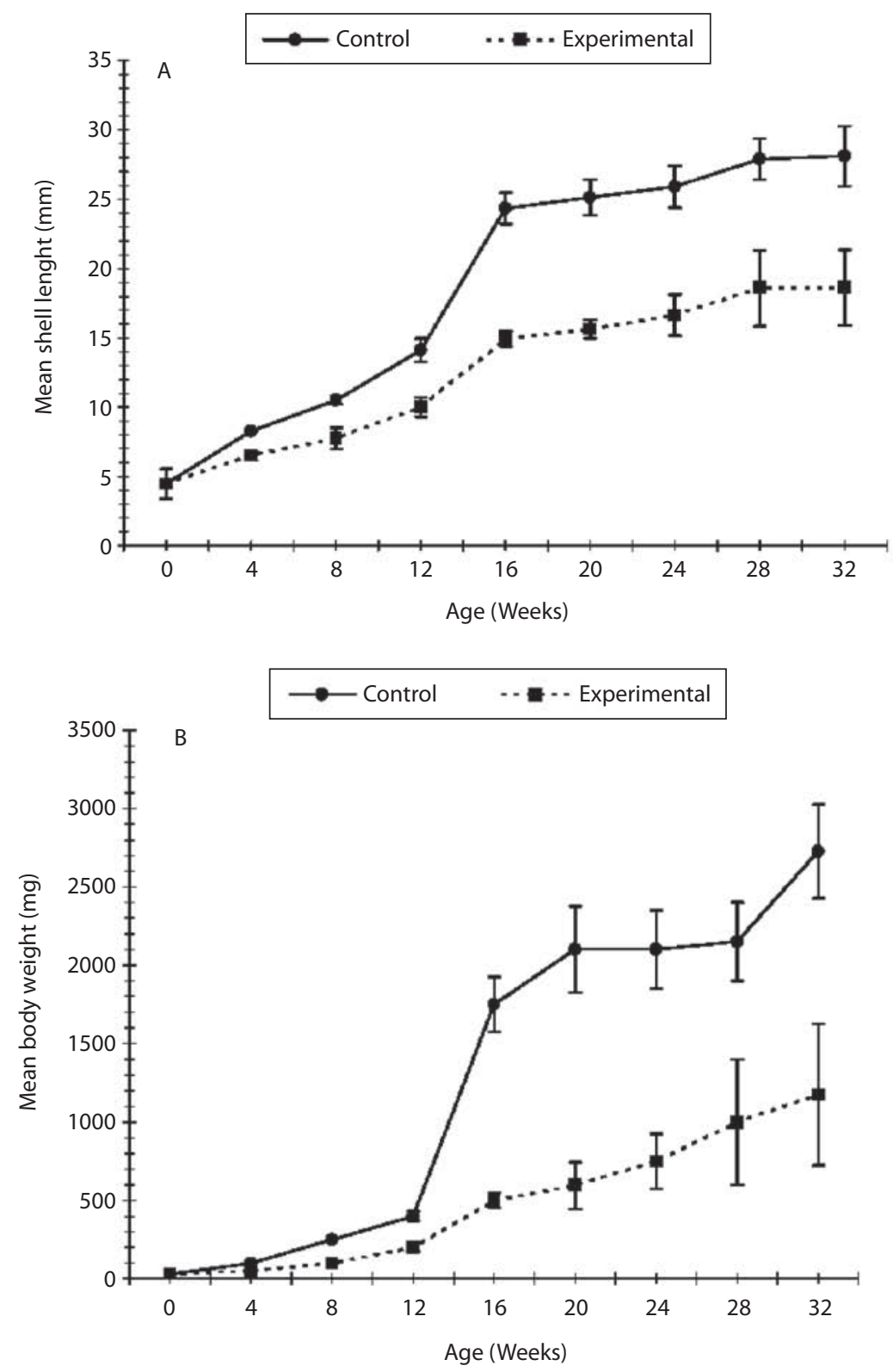

Fig. 1. Mean growth of L. flammea reared in groups of 10 snails with calcium (Control) or without calcium (Experimental) added to food as indicated by Shell length (a) and Body weight (b).

clutches containing 188 eggs. When these snails were dissected at the end of the experiments the shells of the snails deprived of calcium was $23.4 \%$ of the weight of snail compared to $28.9 \%$ in the control group. There were no eggs produced by the two 50 -snail groups during the period of observation.

Life time utilization of calcium: There were three feeding peaks in L. flammea (Fig 4a). 

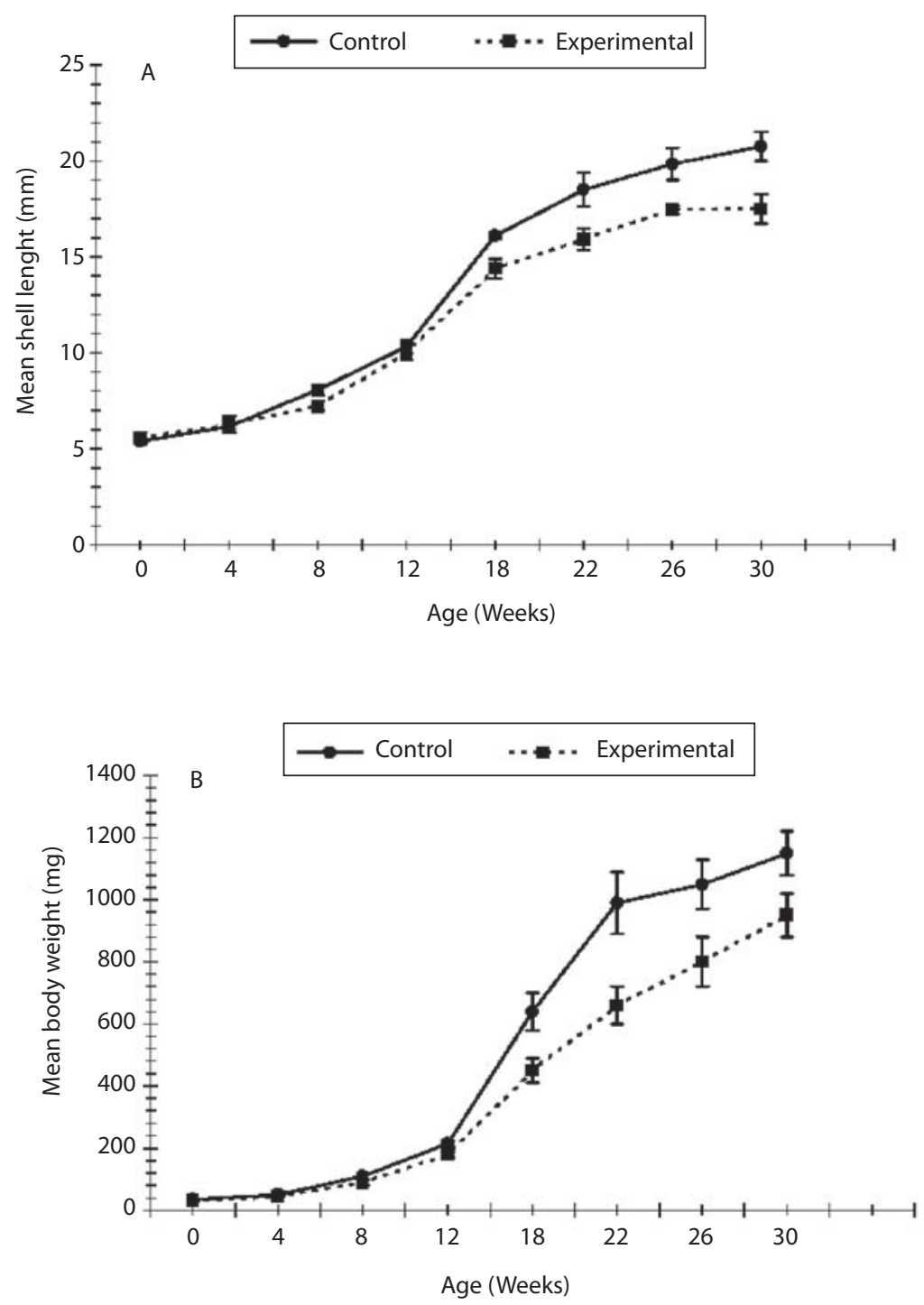

Fig. 2. Mean growth of L. flammea reared in a group of 50 snails with calcium (Control) or without calcium (Experimental) added to food as indicated by Shell length (a) and Body weight (b).

In the first three months of life which correspond to the first feeding peak, food intake increased from $2 \mathrm{~g}$ per month to $15.5 \mathrm{~g}$ in the first peak while the amount of calcium ingested by the snail increased from $0.5 \mathrm{~g}$ to $12.0 \mathrm{~g}$ per month in the first 3 months of life (Fig. 4a). The second feeding peak occurred when the snail was 6 months old when the food intake increased to $28 \mathrm{~g}$ while the last occurred at 10 months of age, with food intake of $34 \mathrm{~g}$. While the amount of food increased, however, the amount of calcium ingested during the second peak decreased gradually to $4.0 \mathrm{~g}$ per month in the 4 th and 5 th month. During the 3 rd feeding peak the amount of calcium stabilized at between 0.5 and $3.0 \mathrm{~g}$ per month. When the snail was 13 months old, 


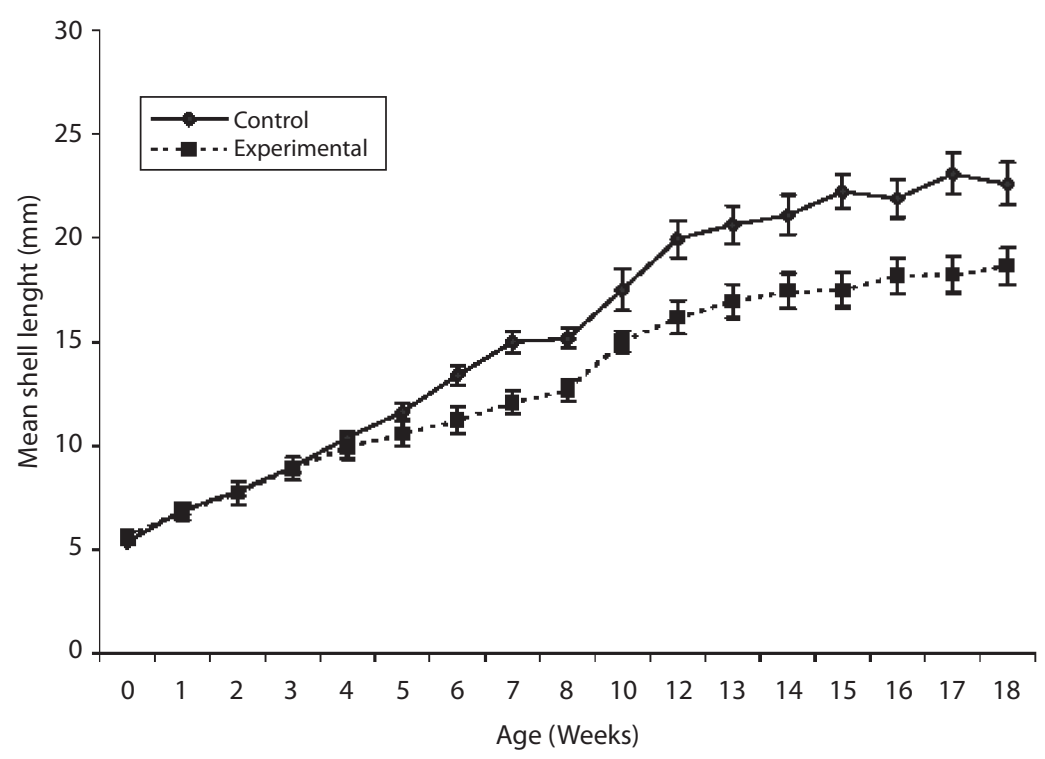

Fig. 3. Mean increase in shell length of L. flammea reared singly with calcium (Control), or without calcium (Experimental) added to food. The experiment was terminated shorly before the start of egg production.

there was another period of egg production which was not accompanied by a feeding peak.

The period of highest weight gained by the snails was between the 1st and 6th month (Fig. 4b) and then dropped between 6 and 12 months which correspond to the period of egg production. There was a small growth again at 13 months when fewer numbers of eggs were produced.

The snails started egg-laying at 5 months producing 45 eggs and there are three peaks of egg production. The first was between 6 and 8 months (535 eggs), the second at between 10 and 11 months (350 eggs) and the third at 13 to 14 months (310 eggs) respectively (Fig. 4c). Egg-laying continued in the second year of life but the number dropped to 40 eggs at the time the experiment was terminated at 15 months due to death by natural cause.

\section{DISCUSSION}

In this study, calcium deficiency in $L$. flammea has been shown to result in a decrease in the rate of growth of snails raised under laboratory condition. The results, particularly thosefor the snails reared singly showed that the effect of calcium deprivation was barely noticeable until after week four. Before starting with the experiments, the hatchlings, like most pulmonates, eat their egg shell as well as the eggs which fail to hatch (Ghose 1959, Rees 1951, Owiny 1974, Plummer 1975, Hodasi 1979, Pawson and Chase 1984). This initial ingestion of calcium ensures that the snail has sufficient material to strengthen the shell after hatching and thereafter they rely on their food supply and a calcium rich soil for further calcium. Hatching asynchrony within a clutch may prompt egg cannibalism by early hatchlings (Baur 1994, Desbuquois 1997) and the production of unfertilized nurse or trophic eggs provides an additional source of calcium (Baur 1994). Egg cannibalism improves the survival prospects of Helix hatching (Desbuquois 1997) and the production of nurse eggs anticipates egg cannibalism, perhaps to supply calcium to hatchlings from eggs whose calcium concentration cannot be raised much 

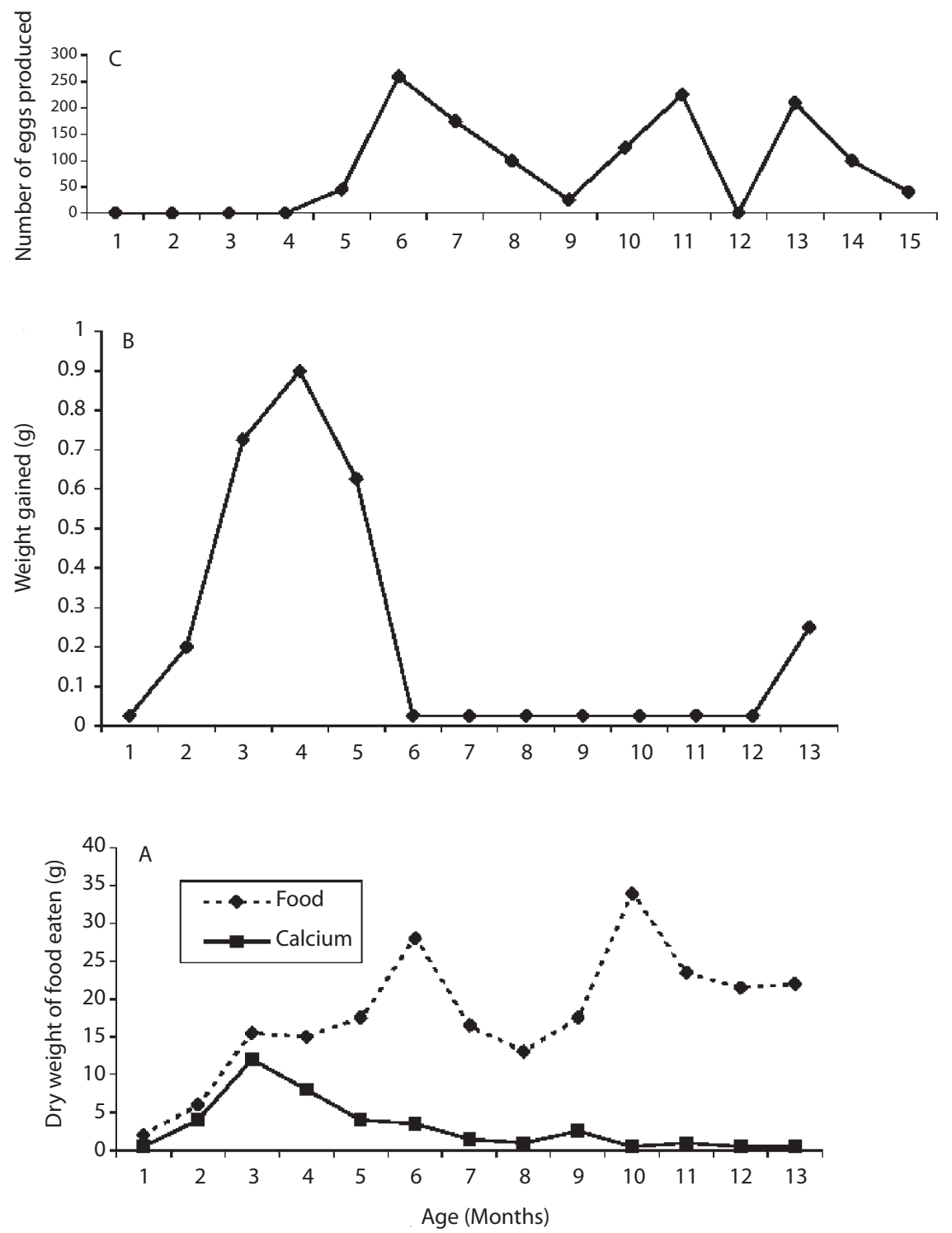

Fig. 4. Amount of dry food ingested (a), weight gained (b), number of eggs produced by L. flammea. Observations started when the snails were hatched.

above 10\% (Beeby and Richmond 2001). This strategy would require an abundance of labile calcium (Beeby and Richmond 2001). According to Stephanou (1986) young snails have lower calcium requirement than they do at maturity, however, snail hatchlings need to build a strong shell soon after emergence and the parental effort extends in some species to producing calcium-rich faeces or coating the egg with a layer of calcium rich soil or as in aquatic species, select sites for oviposition which provide a supply of calcium after emergence (Tompa 1980).

In the life time utilization of calcium, three feeding peaks were observed in L. flammea. The first feeding peak, when a large amount 
of chalk was eaten, corresponds to the period of growth. The second and the third feeding peaks correspond to the periods of egg production during which the amount calcium ingested by the snail was lower than during the first peak. The need for calcium is critical to the snail, especially during the earlier period of life and before the commencement of egg laying but surprisingly calcium consumption decreased appreciably during the actual period of egg laying in L. flammea indicating that the snail stores calcium in the body until needed. There is a considerable mobilization of calcium during egg production in Helix, some of which is derived indirectly from the digestive system (Tompa and Wilbur 1977, Beeby and Richmond 2001) and Deroceras has been estimated to lose about $20 \%$ of their total calcium reserve at each oviposition (Fournie and Chetail 1982). Over the life of the slug Deroceras and its several egg layings, between one third and a half of the total metabolised calcium is passed to the egg. The size of the labile calcium available to the eggs may be critical for their success (Fournie and Chetail 1982, Beeby and Richmond 1998), most of which is mobilized from the parent's hepatopancreas and shell (Fournie and Chetail 1982).

Uniformity with age in efficiency of absorption of calcium ion was reported by Greenaway (1971) for Lymnaea stagnalis; however the present study showed that the amount of calcium ingested by L. flammea fluctuated with growth and reproduction. Until the snail was 3 months old, a large amount of calcium was ingested but this decreased to very low levels from 4 to 13 months after the onset of oviposition. The egg peak observed at 13 months in L. flammea was not accompanied by a feed peak, an indication that probably body reserves were used to produce this last egg peak as the snail lives for about 15 to 22 months and has one or two breeding seasons, with very few surviving to the end of their second year (Egonmwan 2004). Egg production by Helix aspersa exposed to calcium-poor soil was approximately doubled when calcium carbonate was supplied during the second half of the experimental period (Crowell 1973, Tompa
1984) and they retain $20 \%$ of the ingested calcium and some land snails refuse to mate in the laboratory under low calcium conditions (Tompa 1984).

Tompa and Wilbur (1977) found that there is about $70 \%$ increase (from 5.89 millimol to 9.93 millimol) in the total blood calcium in Helix aspersa during egg-laying and this high level was maintained throughout the reproductive period, becoming normal again after the last egg was laid. Differences in time to hatching, egg size, the number of eggs in a clutch and the number of clutches in populations of Arianta sp. were most probably related to shell size (Baur and Baur 1997), which indirectly represent a measure of total calcium (Beeby and Richmond 2001).

When the external supply of calcium was limiting, growth was reduced in L. flammea. Thomas and Lough (1974) found that the growth and natality rates of the freshwater snail Biomphalaria glabrata are enhanced by the net uptake of calcium from the external medium. Calcium provision to the eggs is one key adaptation to a terrestrial habitat in gastropods (Tompa 1980) and meeting this demand at oviposition is likely to represent a considerable cost to the parents. Local adaptations might be expected to reflect essential metal availability (Beeby and Richmond 2001). Snails which grow on areas with low level of toxic metals that may slow the absorption of calcium have a larger calcium reserve even after an oviposition (Beeby and Richmond 2001). In Natalina cafra, Appleton and Heeg (1999) observed that this carnivorous land snail attach the empty shells of some victims to the posterior end of the foot and carry them for up to 4 days; at the end of the period, the shell has been reduced to the consistency of tissue paper as most of the calcium rich matrix has been removed. Since not every victim's shell is decalcified, the authors believe that the removal of calcium by Natalina cafra from some may be due to a calcium demand for building or repairing its own shell, egg laying or preparatory to aestivation.

The snails reared singly showed reduced growth rate when deprived of external calcium 
source as the communally reared snails deprived of calcium. While this growth differential was pronounced in the snails reared singly, it was not very pronounced in the communally reared snails due to the adverse effects of high snail density on normal growth as reported by Egonmwan (1991). It was observed during this study that the communally reared snails resort to cannibalism or feed on the shell of dead snails. Cannibalistic egg eating in newly hatched snails has also been observed in Arianta arbustorum (Baur 1986) and results in accelerated growth. The amount of calcium provided by food is therefore significantly less than the snail's requirement and the snails will benefit markedly from external calcium source, particularly in the early stage, as the amount of calcium ingested during reproduction when the snail is producing shelled eggs is actually very small.

Soil which contain useable carbonates and total calcium levels exert a significant beneficial effect on snail growth and a high level of exchangeable calcium and magnesium in the soil seems favourable to snail growth although calcium is taken up selectively while soil magnesium increase (Gomot et al. 1989) and the active substances in the soil are effective when taken in by the digestive route. Studies carried out by Crowell (1973), Dan (1978), Cowie and Cain (1983), Fournié and Chatail (1982) confirm the need to add lime or calcium carbonate to the diet of terrestrial snails to prevent dwarfing except when the snails are reared on very calcareous soils (Elmslie 1988, Johannessen and Solhøy 2001).

\section{ACKNOWLEDGMENTS}

The author thanks Hansel Erhie for help with the statistical analysis and Amenze Egonmwan for valuable assistance in the preparation of the figures.

\section{RESUMEN}

Estudié el efecto de agregar calcio al alimento sobre el desarrollo del caracol pulmonado africano Limicolaria flammea (Müller). La cantidad de calcio tuvo una correlación positiva con el peso corporal ( $\mathrm{T}$ de Student, $\mathrm{p}<$ $0.01 ; \mathrm{r}=0.96, \mathrm{p}<0.0001)$ y la longitud de concha ( $\mathrm{T}$ de Student, $\mathrm{p}<0.01 ; \mathrm{r}=0.96, \mathrm{p}<0.00001)$. Los caracoles que no recibieron calcio murieron en gran cantidad y no produjeron huevos. En un experimento a largo plazo, hubo picos de consumo del calcio y el mayor aumento de peso fue en los seis meses iniciales. Los picos de producción de huevos fueron entre los seis y los ocho meses (535 huevos), entre los diez y once meses ( 350 huevos) y en los meses 13 y 14 (310 huevos).

Key words: calcio, crecimiento, uso durante el periodo vital, ovoposición, Limicolaria, Achatinidae.

\section{REFERENCES}

Appleton, C.C. \& J. Heeg. 1999. Removal of calcium by Natalina cafra (Pulmonata: Rhytidae) from the shells of its prey. J. Moll. Stud. 65: 271-273.

Baur, B. 1986. The influence of cannibalistic egg-eating on the growth of young Arianta arbustorum, Snail farm. Res. 1: 9-17.

Baur, B.1994. Parental care in terrestrial gastropods. Experientia 50: 5-14.

Baur, A. \& B. Baur.1997. Seasonal variation in size and nutrient content of eggs of the land

snail Arianta arbustorum. Invert. Reprod. Dev. 32: 55-62.

Baur, A., B. Baur.\& L. Froberg. 1994. Herbivory on calcicolous lichens-different food preferences and growth rates in two coexisting land snails. Oecologia 98: 313-319.

Beeby, B. 1991. Toxic metal uptake and essential metal regulation in terrestrial invertebrates: a review, p. 65-89. In M. C. Newman \& A. W. McIntosh, (eds.), Metal Ecotoxicology-Concepts and Applications. Lewis, London.

Beeby, A. \& L. Richmond. 1988. Calcium metabolism in two populations of Helix aspersa on a high lead diet. Arch. Environ. Contam. Toxicol. 17: 507-511. 
Beeby, A. \& L. Richmond. 2001. Calcium provision to eggs in two populations of Helix aspersa by parents fed a diet high in Lead. J. Moll. Stud. 67: 1-6.

Boycott, A.E. 1934. The habitats of land mollusca in Britain. J. Ecol. 22: 1-38.

Chang, H.W. \& J.M. Emlen. 1993. Seasonal variation of microhabitat distribution of the polymorphic land snail Cepaea nemoralis. Oecologia 93: 501-507.

Cowie, R.H. \& A.J. Cain. 1983.Laboratory maintenance and breeding of land snails with example from Helix aspersa. J. Moll. Stud. 49: 176-179.

Crowell, H.H. 1973. Laboratory study of calcium requirements of the brown garden snail, Helix aspersa Müller. Proc. Malacol. Soc. London 40: 491-503.

Dallinger, R., B. Berger., R. Triebskorn-Köhler \& H. Köhler. 2001. Soil ecology and ecotoxicology, p. 489-525. In G.M. Barker (ed.), The Biology of Terrestrial mollusks. Cab International, Oxford, England.

Dan, N.A. 1978.Studies on the growth and ecology of Helix aspersa Müller. Ph.D. dissertation, University of Manchester, Manchester, United Kingdom.

Desbuquois, C. 1997. Influence of egg cannibalism on growth, survival, and feeding in hatchlings of the land snail Helix aspersa Müller (Gastropoda, Pulmonata, Stylommatophora). Reprod. Nutr. Dev. 37: 191-202.

Dytham, C. 2004. Choosing and using statistics: a biologist guide. Blackwell, London.

Egonmwan, R.I. 1991. The effects of population density on growth rates in Limicolaria flammea Müller. J. Moll. Stud. 58: 57-64.

Egonmwan, R.I. 2004. Maturation timing in the land snails, Archachatina marginata ovum (Pfeiffer) and Limicolaria flammea (Müller). Invert. Reprod. Dev. 46: 159-172.

Elmslie, L.J. 1988. Studies on the feeding of newly hatched Helix aspersa. Snail Farm. Res. 2: 45-48.

Fournie, J. \& M. Chetail. 1982. Evidence for a mobilization of calcium reserves for reproduction requirements in Deroceras reticulatum (Syn: Agriolimax reticulatus) (Gastropoda: Pulmonata). Malacologia 22: 285-291.

Ghose, K.C. 1959. Observations on the mating and oviposition of two land pulmonates, Achatina fulica
Bowdich and Macrochlamys indica Godwin-Austen. J. Bombay Nat. Hist. Soc. 56: 183-187.

Gomot, L., S. Gomot, A., Boukras. \& S. Bruckert. 1989. Influence of soil on the growth of the land snail Helix aspersa: An experimental study of the absorption route for the stimulating factors. J. Moll. Stud. 55:1-7.

Greenaway, P. 1971. Calcium regulation in the freshwater mollusc, Limnaea stagnalis (L.) (Gastropoda: Pulmonata). 1. The effect of internal and external calcium concentration. J. Exp. Biol. 54: 199-214.

Hanley, M.E., M. Fenne. \& P.J. Edwards. 1995. The effect of seedling age on the likelihood of herbivory by the slug Deroceras reticulatum. Funct. Ecol. 9: 754-759.

Heller, J. \& M. Magaritz. 1983. From where do land snails obtain the chemicals to build their shells? J. Moll. Stud. 49: 116-121.

Hodasi, J.K.M. 1979. Life-history studies of Achatina (Achatina) achatina Linné. J. Moll. Stud. 45: 328-339.

Ireland, M.P. 1982. Sites of water, zinc and calcium uptake and distribution of these metals after cadmium administration in Arion ater (Gastropoda: Pulmonata). Comp. Biochem. Physiol. 73A: 217-221.

Ireland, M.P. 1991. The effect of dietary calcium on growth, shell thickness and tissue calcium distribution in the snail Achatina fulica. Comp. Biochem. Physiol. 98A: 111-116.

Ireland, M.P. \& J.A. Marigomez. 1992. The influence of dietary calcium on the tissue distribution of $\mathrm{Cu}, \mathrm{Zn}$, $\mathrm{Mg}$, and $\mathrm{P}$ and the histological changes in the digestive gland cells of the snail Achatina fulica Bowdich. J. Moll. Stud. 58: 157-168.

Johannessen, L.E. \& T. Solhøy. 2001. Effects of experimentally increased calcium levels in the litter on terrestrial snail populations. Pedobiologia 45: 234-242.

Kriajev, L., I. Otremski. \& S. Edelstein. 1994. Calcium cells from snail: Response to vitamin D metabolites. Calcif. Tiss. Int. 55: 204-207.

Linhart, Y.B. \& J.D.Thompson. 1995. Terpene-based selective herbivory by Helix aspersa (Mollusca) on Thymus vulgaris (Labiatae). Oecologia 102: 126-132.

Luchtel, D.L. \& I. Deyrup-Olsen. 2001. Body Wall: Form and Function, p. 147-178. In G. M. Barker (ed.). The Biology of Terrestrial Molluscs. CAB International, Oxford, New York. 
McKillpop, W.B. \& A.D. Harrison. 1972. Distribution of aquatic gastropods across an interface between the Canadian Shield and limestone formations. Can. J. Zool. 50: 1433-1445.

Owiny, A.M. 1974. Some aspects of the breeding of the equatorial land snail Limicolaria martensiana (Achatinidae: Pulmonata). J. Zool. London 172: 191-206.

Pawson, P.A. \& R. Chase. 1984. The life-cycle and reproductive activity of Achatina fulica (Bowdich) in laboratory culture. J. Moll. Stud. 50: 85-91.

Peake, J.F. 1978. Distribution and ecology of the Stylommatophora, p. 429-526. In V. Fretter \& J.F. Peake (eds.). Pulmonates: vol.2A, Systematic, Evolution and Ecology. Academic, London.

Plummer, J. 1975. Observation on reproduction, growth, and longevity of a Laboratory colony of Archachatina (Calachatina) marginata (Swainson), subspecies ovum. Proc. Malacol. Soc. London 41: 395-413.

Rees, W. J. 1951. The giant African snail. Proc .Zool. Soc. London 120: 577-598.

Simkiss, K. \& A. Z. Mason. 1983. Metal ions: metabolic and toxic effects, p. 102-164. In P. W. Hochachka (ed.). The Mollusca: Environmental Biochemistry and Physiology. Academic, New York.
Simkiss, K. \& K.M. Wilbur. 1977. The molluscan epidermis and its secretions, p. 35-76. In R.I.C. Spearmen. (ed.). Comparative Biology of Skin. Academic, London.

Stephanou, D. 1986. Experiments on the nutrition of Helix cincta (Kolbert) and Helix aspersa (Muller). Snail Farm.Res. 1: 42-49.

Thomas J.D. \& A. Lough, 1974. The effects of external calcium concentration on the rate of uptake of this ion by Biomphalaria glabrata (Say). J. Anim. Ecol. 43: 861-871.

Tompa, A.1980. Studies on the reproductive biology of gastropods: part III: calcium provision and the evolution of terrestrial eggs among gastropods. J. Conchol. 30: $145-154$

Tompa, A.S. 1984. Land snails (Stylommatophora), p. 47-140. In A. S. Tompa, N.H., Verdonk \& J. A. M. Biggelaar (eds.). Mollusca: Reproduction, Vol.7.Academic, London.

Tompa, A.S. \& N. Watabe. 1976. Calcified arteries in a gastropod. Calcif. Tiss. Res. 22: 159-172.

Tompa, A.S. \&. K.M. Wilbur. 1977. Calcium mobilization during reproduction in snail Helix aspersa. Nature 270: $53-54$

Wagge, L.E. 1952. Quantitative studies of calcium metabolism in Helix aspersa. J. Exp. Zool. 120: 311-342. 
